\title{
"Hedonic Value Perception for Cellular Phone: An Exploratory Study of Indian Consumers"
}

\author{
Arpita Pandey \\ Research Scholar BIT (Mesra) 404,Tulip,Kesar Garden Sec.20, Kharghar, NaviMumbai
}

\begin{abstract}
This exploratory research tries to identify the determinants which affect the attitude of a buyer. The study explores the psychographic, socio-economic and demographic dimension and finds to what extant these factors affect the value perception of the product. Study tries to identify whether product is used as functional product or as a status symbol or luxury product Previous research has established that hedonism plays a strong role in positioning the product, but how individuals' dimensions play important role in determining product's luxury image has not been explored deeply. This research attempts to find the differentiator of hedonism of non food products and evolve a model that can help to predict the determinants effecting hedonic value perception value of a product. Data for the research was collected from different inner and outer cities of India, using quota sampling technique, and respondents were contacted through the shop stop method. The questions were rated on a 5-point Likert scale. All measures were evaluated on SPPS 16. The results show that the hedonic values perception for non food products of inner city consumers depends mainly on order wise age, lifestyle, and education of the buyer where as for outer city it depends on education, income and marital status of the consumers. Results also showed the influence of ethnicity in consumers' hedonism for the product.
\end{abstract}

Key Words: Hedonism, Demographic, Buying Behavior, Non Food Products, Cellular phone

\section{Introduction}

Consumers often face difficulty to choose between hedonic and utilitarian alternatives. These alternatives are partly driven by emotional desires and partly by cold cognitive deliberations. Hence, these choices represent an important domain of consumer decision-making. Emotional desires can often dominate functional motives in the choice of products (Maslow 1968). For example, an educated person will find buying a book, as hedonic where as an uneducated or less educated person may not feel the same.

Babin et al (1994) studied that consumer have different motives for shopping like gratitude. Functional, emotional and hedonic. Among them utilitarian motive is of primary importance. But with the evolution of organized retailing luxury shopping is increasing day by day and transforming the shopping behavior of buyers and modernizing their life style. Coming across the above foundation, as Batra and Athola (1991) state, the consumers' perception is based on the degree to which the products in question satisfy hedonic and utilitarian objectives, few question arises: why two people perceive the same product differently? why one find it luxury while other finds that only task completer ? Whether perception is effected by products own intrinsic or extrinsic attributes or is it buyer's orientations which changes the perception of a product. This research focus to study the influence of consumers' determinants on hedonic value perception for non food products .

\section{Review Of Literature}

Cowling and Cubbin, (1972). First used the term hedonic for price regulation for quality. Hedonic prices were the understood prices of attributes of different products with some unique characteristics associated with them (Rosen, 1974, p 34). Further studies found that hedonic rather than utilitarian attributes of a product elucidate greater amount of variation in prices (Rosen, 1974). Hence hedonic term was used in a financially viable sense.

Most of the studies then were directed to making the hedonic price model stronger in a variety of perspectives like household production model, value of pollution, job satisfaction, real estate valuation, digital computer industry, pediatric services demand and computer services demand, demand for cable television, breakfast cereals and valuation of public goods. In 1982 Hirschman and Holbrook first used the term hedonic in a consumption sense. Which explains the fantasy and emotive aspects of one's experience with products'? After that many researchers like Spegnberg Voss(2003), Batra , Athola,(1991) Dhar et al (2000) have done their research on hedonic value perception consumption.

Wakefield and Inman (2003) suggest that consumers are generally less price sensitive when buying products and services that have hedonic characteristics rather than when buying products of primarily functional nature. Because hedonic products are consumed for fun and fantasy, saving may not be a big concern when one has finally decided to buy something hedonic. Also, people may be willing to spend more on hedonic items because of the relatively infrequent consumption of such items. 
Support for this also comes from O'Curry and Strahilevitz (2001) who show that individuals were more likely to choose a hedonic alternative over a utilitarian one when the probability of receiving the selected item was low and when the probability of receiving the selected item was high they choose utilitarian alternative.

Existing research exhibits that behaviour varies from customer to customer depending on their inclination to interpersonal influence (Bourne 1957; Mason 1981; Bearden and Etzel 1982; Horiuchi 1984; Bushman 1993; Pantzalis 1995).However, a broader perspective of the customer's perception and their motives for purchasing product needs to be explored.

Prior research on purchase decision criteria provides evidence that the relative importance of evaluative criteria may differ based on personal factors such as social class, gender, and relative income level (Williams, 2002). Therefore after identifying the gap in the literature we have decided two goals of our research first to find the hedonic content of the purchase of the product and the second goal was to evolve a model that can help to predict the determinants effecting hedonic value perception for product.

\section{Research Methodology}

Given the objectives of the research, instrument was developed to measure product they bought, hedonic value drawn from for product, the demographic profile of the consumers, their lifestyle.

The demographic data collected include gender, age, marital status, education, family, and income, number of earning members, family size, and children, religious affiliation, ethnicity, occupation, mother tongue and state of origin in India. The Psychographic variables analyzed include shopping orientation, values and lifestyle. Psychographic variables were adapted from the various previous studies according to their relevance in the Indian context and while ensuring the reliability of the items through cronbach's alpha coefficient.

The hedonic value for the product has been calculated by the scales given by spangenberg, voss et al(1997).

Data was collected in the months of September and October over the period of the business hours of the shop (usually $11.00 \mathrm{am}-11.00 \mathrm{pm}$ ) since studies have indicated that consumer behavior varies depending on the time of the day (Skogster, uotila and ojala, 2008; sudman, 1980). Attempt was made to fill approximately a third of the questionnaire during the mid morning hours $(11.00 \mathrm{am}-3 \mathrm{pm})$ and the next one third in the late afternoons $(3 \mathrm{pm}-7 \mathrm{pm})$ and the last one- third after $7 \mathrm{pm}$.It was considered that the visitors who buy the product during the weekdays and weekends could differ substantially along the variables of interest; therefore data was collected on equal number of weekends and weekdays at every destination (Blair, 1983).

Data were analyzed with the statistical package for social sciences (spss) version16 .0 Descriptive statistics, bivariate analysis, discriminant analysis and multivariate analysis were adopted. The sampling method was quota sampling

\section{Research Finding}

Respondents were from different parts of India though a majority was from Maharashtra and Madhya Pradesh. The sample consisted $20.2 \%$ of the age group 18 to $24,28.0 \%$ of the age group 25 to 34 years, $31.6 \%$ of the age group 35 to 44 and $20.2 \%$ of the age group 45 to 54 years. The male and female ratio was tried to kept equal with male contributing $50.5 \%$ and female $49.5 \%$ in the sample ranging from both service and business class and educational qualification from schooling to professionals.

\subsection{Hedonic Value Perception for Cellular Phone}

Ha 1 - Hedonic value perception for Cellular phone is related to demographic profile of the customers .

Table 1. Hedonic Value Perception for Cellular Phone (ANOVA)

\begin{tabular}{|l|l|l|l|l|}
\hline VARIABLE & & df & Mean Square & F \\
\hline Age & Between Groups & 1 & 82.523 & 89.453 \\
\hline Gender & Between Groups & 1 & 31.649 & 268.595 \\
\hline Qualification & Between Groups & 1 & 5.237 & 6.061 \\
\hline Marital Status & Between Groups & 1 & 98.6 & 24.786 \\
\hline Occupation & Between Groups & 1 & 14.844 & 74.073 \\
\hline
\end{tabular}

From the Anova table it is evident that there is significant difference (at.05 level of confidence) in the hedonic value perception and of Cellular Phone and customers demographic profile. Mean squares value indicates that age (82.523) and gender (31.649) are strongly associated with hedonism especially for Cell phone in India .

\subsection{Predictors of Hedonic Value for Cellular Phone}

In order to identify which demographic factor is best predictor of hedonism, series of discriminant analysis has been run with Hedonism as the dependent variable. 
After doing discriminant analysis for all the variables for cell phone, it is inferred that the discriminant function is able to classify $87.7 \%$ of original group cases correctly.

Table $2 \& 3$ shows the value of wilk's lamda and probability value of F-test for statistical significance of the discriminant function which ranges between 0 andland with lower value $(0.420)$ of gender indicating a better discriminating power of it.

From table 2 it can be inferred that $(\mathrm{p}=0.000)$ discrimination between the groups is highly significant.

From table 4 of structure matrix it can be said that gender (..384) qualification (.370) and life style (.174) are the better predictor of hedonic value perception of cellular phone in central and western part of India. Probability is that almost (87\%) customers in these regions would be hedonic for cellular phone .

Table 2. Model summery

\begin{tabular}{|l|l|l|l|l|}
\hline Function & Eigen value & Wilks' Lambda & Chi-square & Df \\
\hline 1 & -9.528 & .096 & 630.446 & 9 \\
\hline
\end{tabular}

Table 3. Model summery

\begin{tabular}{|l|l|l|l|}
\hline & Wilks' Lambda & F & Sig. \\
\hline annual income & 1 & 0.004 & 0.949 \\
\hline Ethnicity & 0.884 & 35.985 & 0 \\
\hline Gender & 0.42 & 378.288 & 0 \\
\hline Occupation & 0.831 & 55.617 & 0 \\
\hline Family Size & 0.799 & 69.093 & 0 \\
\hline Qualification & 0.438 & 351.634 & 0 \\
\hline Age & 0.792 & 71.96 & 0 \\
\hline Marital Status & 0.95 & 14.49 & 0 \\
\hline Life style & 0.778 & 78.025 & 0 \\
\hline
\end{tabular}

Table 4. Model summery (Structure Matrix)

\begin{tabular}{|l|l|l|}
\hline Gender & 0.370 & 0.384 \\
\hline Qualification & 0.174 & \multicolumn{2}{l|}{} \\
\hline Life style & \multicolumn{2}{l|}{} \\
\hline Age & 0.164 & \multicolumn{2}{l|}{} \\
\hline Family Size & 0.147 & -0.118 \\
\hline Occupation & \multicolumn{2}{|l|}{} \\
\hline Ethnicity & 0.075 & \multicolumn{2}{l|}{} \\
\hline Marital Status & -0.001 & \\
\hline annual income &
\end{tabular}

\section{Model Development}

After identifying that gender, qualification and lifestyle are the main predictor for hedonism of cellular phone second set of discriminant analysis was run by taking only these three variables as independent variable and hedonism as dependent variable. Results in table 5 depicts that again qualification come out as strongest predictor (.808) of hedonism.

From table 6 and 7 we prescribe a model taking Unstandardized coefficients discrimination that if the value of discriminant score $(\mathrm{Y})$ for of a customer comes less than -1.453 than he could be considered hedonic for cellular phone. (Model has been successfully tested under similar conditions and predicted $97.7 \%$ cases correctly)

Table 5. Model summery (Structure Matrix)

\begin{tabular}{|l|l|}
\hline Qualification & .808 \\
\hline Gender & .550 \\
\hline Life Style & .106 \\
\hline
\end{tabular}

Table 6. Model summery (Canonical Discriminant Function Coefficients) Unstandardized coefficients

\begin{tabular}{|l|l|}
\hline Qualification & 2.561 \\
\hline Gender & -.161 \\
\hline Life Style & 2.605 \\
\hline (Constant) & -11.498 \\
\hline
\end{tabular}

Table 7. Model summery (Functions at Group Centroids)

\begin{tabular}{|l|l|}
\hline Hedonism & Function \\
\cline { 2 - 2 } & \\
\hline Less Hedonic & 2.818 \\
\hline Hedonic & -1.456 \\
\hline
\end{tabular}




\title{
Prescribed Model
}

\author{
$\mathrm{Y}=-11.498+$ Qualification $\frac{\text { Discriminant Score For Cellular Phone }}{(2.561)+\text { Gender }(-.161)+\text { life style }(2.605)}$
}

\section{Results}

Research shows that gender, qualification and life style are the major determinates for finding hedonism of cell phone graduate males leading the aggressive life style between the age of 18 and 34.preferably service class are more hedonic for cell phone.

(based on structure matrix)

\section{Future Research}

In the course of this research, it has been identified that there are various areas where further research is needed to extend this study to look at hedonic and functional value of the product.

In this study major determinants which affect the hedonic value perception came as gender, qulification and life style. Further research can be done by eliminating other variables used in this analysis except these three and adding some different factors to find relationship between them.

This study does not imply on the food products thus there is a scope for future study in this area.

\section{Conclusion}

The identification of the hedonism in terms of psychographic and behavioral dimensions can assist in designing promotional themes, and socioeconomic and demographic characteristics can facilitate the right marketing mix of the product and developed the better understanding of an emerging consumer market.

With Higher disposable incomes, easy availability of credit and high exposure to media and brands has considerably increased the average propensity to consume over the years. This study can give a platform to companies to position their product correctly in this huge developing market.

\section{References}

[1]. Ahmed, Z.U., Ghingold, M. And Dahari, Z. (2007) Malaysian Shopping Behaviour: An Exploratory Study. Asia Pacific Journal Of Marketing And Logistics 19 (4): 331-348.

[2]. Arnold, M.J. And Reynolds, K.E. (2003), "Hedonic Shopping Motivations”, Journal Of Retailing, Vol. 79 No. 1, Pp. 77-95.

[3]. Assael, H. (2001), Consumer Behavior And Marketing Action, Thomson Learning, London, P. 93.

[4]. Babine, B.J. And Atta way, J. (2000) Atmospheric Affect As a Tool for Creating Value and Gaining Share of Customer. Journal of Business Research 49 (2): 91-100.

[5]. Babin B. \& Giffin M. (2005)“Measuring Hedonic And Utilitarian Shopping Value”, Journal Of Consumer Research, Vol. 20 No. 2, Pp. 644-56.A

[6]. Batra, R. And Ahtola, O.T. (1991) Measuring The Hedonic And Utilitarian Sources Of Consumer Attitudes. Marketing Letters 2 (2): 159-170.

[7]. Bhalla, A.S., Yao, S. And Zhang, Z. (2003),Sacred And The Profane In Consumer Behavior: Theodicy On The Odissey", "Causes Of Inequalities In China, 1952 To 1999", Journal Of Consumer Research, Vol. 16, Pp. 1-38.

[8]. Burke, R. (1997) Do You See What I See? The Future Of Virtual Shopping. Journal Of The Academy Of Marketing Science 25 (4): $352-361$.

[9]. China Daily (2004), “Unique China Defies World's Predictions”, China Daily, June 11, P. 11.

[10]. Churchill, G.A. And Surprenant, C. (1982), “An Investigation Into The Determinants Of Customers' Satisfaction”, Journal Of Marketing Research, Vol. 19 No. 4, Pp. 491-504.

[11]. Harper \& Row. (2006) Consumer Choice Between Hedonic And Utilitarian Goods Consumer Research, No. 24, Pp. 128-31.

[12]. Darden, W.R. And Reynolds, F.D. (1971), "Shopping Orientations And Product Usage Rates", Journal Of Marketing Research, Vol. 8 No. 4, Pp. 505-8.

[13]. Eroglu, S.A., Machleit, K.A. And Barr, T.F. (2005), "Perceived Retail Crowding And Shopping Satisfaction: The Role Of Shopping Values", Journal Of Business Research, Vol. 58 No. 8, Pp. 1146-53.

[14]. Fiore, A.M. And Kim, J. (2007) An Integrative Framework Capturing Experiential And Utilitarian Shopping Experience. International Journal Of Retail \& Distribution Management 35 (6): 421-442.

[15]. Goffman, E. (1959) ‘The Presentation Of Self In Everyday Life.” Garden City, NY: Doubleday And Company.

[16]. Griffin, M., Babin, B.J. And Modianos, D. (2000), "Shopping Values Of Russian Consumers: The Impact Of Habituation In A Developing Economy", Journal Of Retailing, Vol. 76 No. 1,

[17]. Hedonic Consumption”, In Holman, R. And Solomon, R. (Eds), ( 2011) ,Advances In Consumer Research, Vol. 18, Association For Consumer Research, Provo, UT, Pp. 428-34. 